\title{
Inovasi Pelayanan Publik E-Pendampingan Halo Jaksa Kejaksaan Negeri Tebo Dalam Mengatasi Masalah Pembangunan Gedung Poliklinik Rsud Sultan Thaha Syaifudin Kabupaten Tebo
}

\author{
Yuda Tri Putra, Lince Magriasti \\ Universitas Negeri Padang, Padang, Indonesia
}

\begin{tabular}{l} 
Article Info \\
\hline Article history: \\
Received 05 Januari 2022 \\
Publish 08 Januari 2022
\end{tabular}

Keywords:

Development, implementation, E-Pendampingan

Hallo Jaksa.

\section{Info Artikel}

Article history:

Publish 08 Januari 2022
Received 05 Januari 2022

\begin{abstract}
This study describes how the implementation of the public service innovation E-Assisting Halo Prosecutor of the Tebo District Office in overcoming the problem of building a polyclinic building for the Sultan Thaha Syaifudin Regional General Hospital, Tebo Regency. The background of this research is because of development problems in Tebo Regency, especially infrastructure development, one of which is the construction of a polyclinic building for the Sultan Thaha Syaifudin Regional General Hospital, Tebo Regency, because workers are exposed to Covid and there are restrictions on the movement of community activities (PPKM) during the COVID-19 pandemic. This research was conducted with a quasi-qualitative method, data collection techniques using data from interviews, observations and documentation. Selection of informants using purposive sampling technique with validity test using triangulation technique. The results of the study explain how the Halo Prosecutor's E-Assistance is used as a medium for delivering information on development progress and as a communication medium for legal assistance by the Tebo District Attorney in helping to overcome development problems in Tebo Regency, of course, also the problem of building a polyclinic for the Regional General Hospital. Sultan Thaha Syaifudin Tebo. Next, look at the impact of the Halo Prosecutors' E-Assistance in the construction of the Sultan Thaha Syaifudin Tebo Regional General Hospital polyclinic building
\end{abstract}

\begin{tabular}{l}
\hline ABSTRAK \\
\hline Penelitian ini menjelaskan tentang bagaimana penerapan inovasi pelayanan publik E- \\
Pendampingan Halo Jaksa Kejaksaan Negeri Tebo dalam mengatasi masalah pembangunan \\
gedung poliklinik Rumah Sakit Umum Daerah Sultan Thaha Syaifudin Kabupaten Tebo. \\
Latar belakang penelitian ini karena adanya permasalahan pembangunan di Kabupaten Tebo \\
khusunya pembangunan infrastruktur salah satunya yaitu pembangunan gedung poliklinik \\
Rumah Sakit Umum Daerah Sultan Thaha Syaifudin Kabupaten Tebo dikarenakan pekerja \\
yang terpapar covid serta adanya pembatasan peregerakan kegiatan masyarakat (PPKM) di \\
masa pandemi covid-19. Penelitian ini dilakukan dengan metode kuasi kualitatif, teknik \\
pengumpulan data menggunakan data hasil wawancara, observasi serta dokumentasi. \\
Pemilihan infoman menggunakan teknik purposive sampling dengan uji keabsahaan \\
menggunakan teknik triangulasi. Hasil penelitian menjelaskan bagaimana E-Pendampingan \\
Halo Jaksa tersbut digunakan sebagai media penyampaian informas progres pembangunan \\
serta sebagai media komunikasi untuk bantuan p endampingan hukum oleh Kejaksaan Negeri \\
Tebo dalam membantu mengatasi permasalahan pembangunan yang ada di Kabupaten Tebo \\
tentunya juga permasalahan pembangunan gedung poliklinik Rumah Sakit Umum Daerah \\
Sultan Thaha Syaifudin Tebo. Selanjutnya melihat bagaimana dampak yang dihasilkan dari \\
adanya E-Pendampingan Halo Jaksa tersebut dalam pembangunan gedung poliklinik Rumah \\
Sakit Umum Daerah Sultan Thaha Syaifudin Tebo. \\
\hline This is an open access article under the Lisensi Creative Commons Atribusi-BerbagiSerupa \\
4.0 Internasional
\end{tabular}

Corresponding Author:

Yuda Tri Putra

Universitas Negeri Padang, Padang, Indonesia

Email : Yudatriputra03@Gmail.Com 


\section{PENDAHULUAN}

Perkembangan teknologi informasi dari masa ke masa sangat berpengaruh dalam kehidupan manusia. Pada era teknologi seperti saat sekarang ini, dapat mempermudah kebutuhan utama manusia dalam kegiatan sehari-harinya, termasuk ruang lingkup pemerintahan. Teknologi informasi sangat berperan penting guna mempermudah kegiatan Birokrasi pemerintahan dalam menjalankan roda-roda pemerintahan. Di zaman saat ini, pemerintah diharuskan mampu beradaptasi, menguasai serta menerapkan teknologi informasi dalam mememecahkan masalah-masalah yang dihadapi oleh pemerintah salah satunya adalah masalah pembangunan.

Pembangunan penting karena suatu daerah dikatakan maju apabila dapat dinilai dari aspek pembangunanya apabila daerah itu ingin maju maka tentu pembangunan di daerah tersebut harus berjalan dengan baik. Pembangunan yang dilakukan tentu dapat dinilai oleh masyarakat secara langsung salah satu cara mudahnya dengan menilai pembangunan yang kasat oleh mata yaitu pembangunan fisik atau infrastruktur yang dapat dinilai langsung oleh siapapun tanpa harus melihat data secara langsung. Dalam proses pembangunan diperlukan kerjasama antar stekholder, yaitu pemerintah, swasta serta masyarakat. Pembangunan yang baik dapat terwujud apabila para stekholder tersebut melaksanakan peranya masing-masing secara maksimal sehingga nantinya akan tercapainya pembangunan yang secara otomatis dapat meningkatkan kesejahteraan masyarakat.

Kabupaten Tebo merupakan salah satu kabupaten baru yang ada di Provinsi Jambi yang dimekarkan pada tahun 1999. Sebagai kabupaten yang baru berusia 22 tahun tentunya sedang giatgiatnya melakukan pembangunan khusunya pembangunan infrastruktur penunjang kesejahteraan masyarakat, namun dalam pelaksanaan pembangunan tersebut juga seringkali terjadi beberapa kendala yang dialami oleh Pemerintah Kabupaten Tebo dikarenakan adanya persoalan secara teknis maupun non-teknis. Kendala tersebut tentu menjadi penghambat dalam proses pembangunan tersebut di Kabupaten Tebo.

Terlebih dengan kondisi krisis seperti sekarang ini dengan adanya pandemi Covid-19 yang menghambat hampir seluruh aspek kehidupan manusia termasuk kegiatan pemerintah seperti proses pembangunan. Salah satu contoh permasalahan pembangunan di Kabupaten Tebo yaitu Pembangunan secara infrastruktur pada gedung Poliklinik di Rumah Sakit Umum Daerah Sultan Thaha Syaifudin Tebo (RSUD STS Tebo). Pihak swasta selaku pelaksana mengalami kendala pada tenaga kerja berasal dari Provinsi Jawa Tengah, yang mana tenaga kerja tersebut tidak diberi akses masuk ke Kabupaten Tebo dikarenakan adanya kebijakan PPKM dan beberapa tenaga kerja terdampak positif Covid-19. Pihak swasta berkomunikasi kembali dengan pihak RSUD dan Dinas PUPR (Pekerjaan Umum dan Perumahan Rakyat) selaku pihak yang terlibat dalam pembangunan untuk mencari solusi. Namun, pihak RSUD dan Dinas PUPR tidak berani melakukan tindakan apapun dikarenakan takut akan menyalahkan aturan yang ada, sehingga pembangunan tersebut menjadi terhenti.

Melihat situasi tersebut, pihak RSUD mengajukan permohonan Pendampingan hukum melalui E-pendampingan Halo Jaksa yang ada di Kejaksaan Negeri Tebo untuk mendapatkan solusi terhadap permasalahan yang ada, agar tetap pembangunan di RSUD STS Tebo berjalan dengan baik. Menindak lanjuti banyaknya permasalahan yang terjadi pada saat proses pembangunan di Kabupaten Tebo, pada 16 Februari 2021 bertempat di Aula Kejaksaan Negeri Tebo, berdasarkan asas Hukum ditandatanganilah Nota Kesepakatan atau (MOU) Nomor 188/04/Hk/2021 dan B406/L.5.17/Gs/02/2021 antara Kejaksaan Negeri Tebo dan Pemerintah Kabupaten Tebo tentang penanganan permasalahan hukum dibidang Perdata Dan Tata Usaha Negara. Sehingga seluruh OPD Di lingkup Pemkab Tebo akan mendapatkan fasilitas pendampingan hukum.

E-pendampingan Halo Jaksa sebelumnya bernama Aplikasi Halo Jaksa dibuat pada tahun 2017, yang mana merupakan inovasi pelayanan hukum kejaksaan berbasis online satu-satunya di Provinsi Jambi bahkan di Indonesia pada saat itu. Adapun fitur yang terdapat dalam aplikasi tersebut yakni: Konsultasi Hukum, Bantuan Hukum, Informasi Tentang Penanganan, Penyelesaian 
Perkara Pidum, Laporan Dugaan Tindak Pidana Korupsi, Pendampingan Tim Pengawal Pengaman Pemerintah dan Pembangunan Daerah (TP4D) atau Laporan mal praktek Jaksa. Aplikasi tersebut juga dijadikan contoh sebagai aplikasi pelayanan di beberapa Kejari Kabupaten/Kota di Indonesia seperti Kejaksaan Negeri Bangka Barat, Kejaksaan Negeri Berau, Kejaksaan negeri Kebumen dan keajaksaan negeri pemalang. Pada tahun 2018, Kejari Tebo meraih penghargaan atas prestasinya melakukan inovasi pelayanan publik berbasis teknologi informasi oleh Kejaksaan Tinggi Jambi. Penghargaan tersebut diterima secara langsung oleh Bapak Teguh Suhendro, SH, M.Hum selaku Kepala Kejari Tebo.

Namun pada tahun 2019 hingga 2021 aplikasi Halo Jaksa ini sempat terhenti dikarenakan pergantian pimpinan Kejaksaan Negeri beserta juga admin dari halo jaksa tersebut. Sehingga terlihat tidak adanya komitmen serta edukasi lanjutan tentang layanan halo Jaksa tersebut dari para pimpinan maupun pegawai di Kejaksaan Negeri Tebo pada masa itu. Oleh karena itu, masyarakat tidak lagi dapat menggunakan aplikasi tersebut. Seiring berjalannya waktu terdapat pergantian Kejari Tebo. Pada februari 2021, Bapak Imran Yusuf, S.H, M.H selaku Kejari Tebo yang baru melakukan pengaktifan kembali layanan pendampingan hukum tersebut dalam pengadaan barang dan jasa pemerintah yang di beri nama "e-Pendampingan". Layanan tersebut dapat diakses melalui website www.kejari-tebo.go.id.

Pelayanan Pendampingan Kejaksaan Negeri Tebo ini merupakan proses pendampingan hukum dalam bidang Perdata dan Tata Usaha Negara yaitu pada proses pengadaan barang dan jasa pemerintah yang bertujuan untuk mendukung jalannya pembangunan yang dilakukan oleh Pemerintah. Kejaksaan selaku Jaksa pengacara Negara (JPN) dalam prosesnya dapat memberikan pendapat hukum (Legal Opinion) dan pendampingan hukum (Legal Assitance) serta audit hukum (Legal Audit) kepada Pemerintah. Dalam hal ini, pemerintah Kabupaten Tebo sesuai dengan "Peraturan Jaksa Agung No. PER-025/A/JA/11/2015 tentang Petunjuk Pelaksanaan Penegakan Hukum, Bantuan Hukum, Pertimbangan Hukum, Tindakan Hukum Lainya dan Pelayanan Hukum Di Bidang Perdata Dan Tata Usaha Negara" serta dalam UU No. 16 Tahun 2004 tentang Kejaksaan RI pasal 30 butir ke-2 yang menyatakan "Di bidang perdata dan tata usaha negara, kejaksaan dengan kuasa khusus dapat bertindak baik didalam maupun diluar pengadilan untuk dan atas nama negara atau pemerintah". Setiap progres pembangunan dapat di monitor langsung oleh pihak PUPR, Kejaksaan serta OPD yang membangun dan juga masyarakat. Dalam Hal ini menjadi bahan laporan evaluasi kepada Bupati, DPRD dan inspektorat selaku pengawas internal dalam lingkup pemerintahan, Badan Keuangan Daerah selaku pengelola keuangan daerah serta pihak swasta dalam hal ini kontraktor melalui e-Pendampingan ini. Oleh karena itu, penulis tertarik untuk menulis Srkripsi dengan judul "Inovasi Pelayanan Publik E-Pendampingan Halo Jaksa Kejaksaan Negeri Tebo Dalam Mengatasi Masalah Pembangunan Gedung Poliklinik Rumah Sakit Umum Daerah Sultan Thaha Syaifudin Kabupaten Tebo". Seperti apa penerapan pelayanan ePendampingan Halo Jaksa di Kejaksaan Negeri Tebo akan diulas lebih jauh dalam penelitian penulis ini.

\section{a. Konsep e-Goverment sebagai dasar Implementasi.}

Konsep E-Goverment merupakan suatu konsep dimana proses pemerintahan berjalan dengan pemanfaatan-pemanfaatan teknologi informasi dalam mendukung serta membantu pemerintahan dalam menjalankan kegiatan pemerintahan dengan efektif serta efisien.oleh karena itu dalam perwujudanya diawali dengan adanya inovasi-inovasi layanan yang berbasis teknologi informasi dalam memberikan pelayanan baik kepada pemerintah antar pemerintah, pemerintah antar sektor privat serta maupun pemerintah antar masyarakat sehingga proses kegiatan pemerintahan berjalan dengan tepat sasaran serta cepat dan hemat biaya oleh karena itu E-goverment memberikan penjabaran bagaimana menerapkan teknologi informasi dalam menunjang tugas serta fungsi pemerintahan baik di pusat maupun di daerah. 


\section{b. Konsep New Public Service}

Dalam Konsep The New Public Service yang di kemukakan Jannet V. Denhadrt dan Robert B. Denhadrt tahun 2003 menjelaskan bahwa setiap warga negara berhak atas pelayanan publik yang berkualitas dari negara. Serta warga negara berhak mendapatkan perlindungan untuk hak-hak yang dimilikinya. Oleh karena itu setiap warga negara berhak menilai, menolak, dan menuntu pemerintah atas pemenuhan pelayanan publik bagi setiap warga negara Denhardt, J.V. \& Robert (2015).

\section{c. Inovasi Pelayanan Publik.}

Inovasi pelayanan publik merupakan terobosan pembaharuan dari jenis pelayanan baik yang merupakan gagasan atau ide kreatif yang orisinal dan adaptasi modifikasi yang memberikan manfaat bagi masyarakat, baik secara langsung maupun tidak langsung. Dengan kata lain, inovasi pelayanan publik sendiri tidak mengharuskan suatu penemuan baru, tetapi dapat merupakan suatu pendekatan baru yang bersifat kontekstual dalam arti inovasi tidak terbatas dari tidak ada kemudian muncul gagasan dan praktik inovasi, tetapi dapat berupa inovasi hasil dari perluasan maupun peningkatan kualitas pada inovasi yang ada. Untuk itu dalam usaha peningkatan pelayanan publik yang berkualiats kepada masyarkat pemerintah selalu di tuntut untuk berinovasi dalam menemukan ide-ide baru ataupun melakukan perluasan dari pelayanan publik yang lama untuk selanjutnya di olah menjadi sistem pelayanan baru yang lebih inovatif.

\section{d. Konsep Pembangunan.}

Pembangunan penting karena suatu daerah dikatakan maju apabila dapat dinilai dari aspek pembangunanya apabila daerah itu ingin maju maka tentu pembangunan di daerah tersebut harus berjalan dengan baik. Pembangunan yang dilakukan tentu dapat dinilai oleh masyarakat secara langsung salah satu cara mudahnya dengan menilai pembangunan yang kasat oleh mata yaitu pembangunan fisik atau infrastruktur yang dapat dinilai langsung oleh siapapun tanpa harus melihat data secara langsung.

Dalam proses pembangunan diperlukan kerjasama antar stekholder, yaitu pemerintah, swasta serta masyarakat. Pembangunan yang baik dapat terwujud apabila para stekholder tersebut melaksanakan peranya masing-masing secara maksimal sehingga nantinya akan tercapainya pembangunan yang secara otomatis dapat meningkatkan kesejahteraan masyarakat.

\section{METODE PENELITIAN}

Dalam penelitian ini penulis menggunakan metode kuasi kualitatif. Dimana dalam metode kuasi kualitaif ini penggunaan teori masih digunakan sebagai instrumen untuk menemukan masalah, pengumpulan data, sampai dengan analisis data. Jenis dan sumber data dalam metode kuasi kualitatif menggunakan data primer dan sekunder, data primer bersumber langsung dari narasumber yang terkait dengan pembahasan masalah dalam penulisan skripsi penulis, sementara data sekunder bersumber dari literasi seperti buku, jurnal, artikel, berita yang relevan dengan permasalahan yang dibahas dalam skripsi penulis.

Penelitian dengan menggunakan metode kuasi kualitatif ini bertujuan untuk dapat mendeskripsikan dengan jelas bagaimana penerapan Inovasi Pelayanan Publik E-Pendampingan Halo Jaksa Kejaksaan Negeri Tebo dalam mengatasi permasalahan pembangunan gedung Poliklinik RSUD Sultan Thaha Syaifudin Kabupaten Tebo. Pemilihan informan dalam penelitian penulis ini dipilih secara purposive sampling yang mana penulis menetukan informan berdasarkan keterkaitan langsung informan dengan proses permasalahan dalam penelitian penulis. Dalam penelitian ini terdapat 5 orang informan yang terlibat. Teknik pengumpulan data dalam penelitian ini menggunakan teknik triangulasi yaitu wawancara, observasi, serta dokumentasi. Teknik analisis data menggunakan menggunakan model miles dan hueberman biasanya menggunakan istilah analisis data interaktif yang dimana teknik analisis tersebut berlangsung secara interaktif dan terus- 
menerus sampai permasalahan tuntas. Proses ini meliputi data reduksi (reduction data), penyajian data (display data), dan conclusion drawing data atau penarikan kesimpulan.

\section{HASIL TEMUAN DAN PEMBAHASAN}

Berdasarkan temuan peneliti tentang “ Inovasi Pelayanan Publik E-Pendampingan Halo Jaksa Kejaksaan Negeri Tebo Dalam Mengatasi Pembangunan Gedung Poliklinik RSUD Sultan Thaha Syaifudin Kabupaten Tebo " dapat penulis jabarkan dalam pembahasaan berikut ini:

\section{a. Inovasi Pelayanan E-Pendampingan Halo Jaksa Kejaksaan Negeri Tebo.}

Perkembangan inovasi pelayanan publik tak lepas dengan pemanfaatan teknologi informasi, dimasa sekarang mau tidak mau semua aspek kehidupan harus dapat beradaptasi dengan kemajuan teknologi informasi, termasuk dalam bidang pemerintahan sekalipun.

Pemerintah selaku penyedia pelayanan publik dituntut mampu memberikan pelayanan yang prima kepada masyrakat tentunya sesuai denga yang diamanat kan oleh UU No 25 Tahun 2009 sebagai pedomanan penilaian kualitas pelayanan publik di indonesia dan juga sesuai dengan yang diamanatkan oleh Peraturan Menteri PANRB No. 30 Tahun 2014 Tentang Pedoman Inovasi Pelayanan Publik bahwa pemerintah harus selalu melakukan inovasi-inovasi untuk mengembangkan serta membuat ataupun memperbaiki pelayanan publik agar di dapat memberikan pelayanna yang bermutu kepada masyarakat di indonesia.

Hal ini juga yang menjadi dasar pihak Kejaksaan Negeri Tebo mengembangkan inovasi Pelayanan E-Pendampingan Halo Jaksa yang berdasarkan hasil temuan peneliti dari proses wawancara bersama kepala Kejaksaan Negeri Tebo Imran Yusuf, S.H, M.H E-Pendampingan ini pelayanan dalam mendukung pemerintah dalam proses pengadaan barang dan jasa pemerintah khususnya pemerintah Kabupaten Tebo yang menerapkan teknologi informasi dalam proses penerapanya.

b. Penerapan Inovasi Pelayanan Publik E-Pendampingan Halo Jaksa Kejaksaan Negeri Tebo Dalam Mengatasi Masalah Pembangunan Gedung Poliklinik RSUD STS Kabupaten Tebo.

Inovasi pelayanan publik merupakan suatu gagasan atau ide pembaharuan yang bersifat orisinil hasil dari pengembangan pelayanan yang telah ada sebelumnya ataupun yang belum ada dan merupakan trobasan baru dari instansi birokrasi pemerintahan tentunya dengan tujuan untuk memberikan pelayanan yang prima baik kepada pemerintah itu sendiri (sesama instansi) ataupun kepada masyarakat.

Dengan kemajuan teknologi informasi pada saat ini tentunya inovasi pelayanan publik harusla menyesuaikan dengan keadaan tersebut dengan mau tidak mau harus beradaptasi dan beralih menerapkan teknologi informasi disetiap pelaksanaan pelayanan kepada masyarakat. Hal tersebut juga sebagai dasar Kejaksaan Negeri Tebo membuat Inovasi Pelayanan Publik Halo Jaksa yang berdasarkan hasil penelitian yang dilakukan oleh peniliti didapatkan bahwa EPendampingan ini merupakan inovasi pelayanan yang dilakukan oleh Kejaksaan Negeri Tebo dalam memberikan layanan dalam bidang perdata dan tata usaha negara khususnya pada porses pengadaan barang dan jasa Pemerintah berupa Legal Assistance / Pendampingan Hukum (dilakukan pada kegiatan pengadaan barang \& jasa yang sedang berlangsung ).

Maka dari itu pada awal tahun 2021 hadirlah E-Pendampingan Halo Jaksa Kejaksaan Negeri Tebo yang berdasarkan hasil wawancara bersama kepala kejaksaan negeri tebo Imran Yusuf, S.H, M.H beliau menjelaskan tujuan pemebentukan E-pendampingan ini yang paling utama adalah untuk mendukung Pemerintah Kabupaten Tebo khususnya dalam membantu memberikan masukan-masukan serta saran dalam mengatasi permasalahan pembangunan di kabupaten Tebo.

Salah satu permasalahan yang didampingin melalui inovasi pelayanan E-Pendampingan Halo Jaksa Kejaksaan Negeri Tebo adalah masalah pembangunan Poliklinik di RSUD Sultan 
Thaha Syaifudin Tebo. Oleh karena itu untuk mengetahui bagaimana Inovasi Pelayanan Publik E-Pendampingan Halo Jaksa Kejaksaan Negeri Tebo Dalam Mengatasi Masalah Pembangunan Gedung Poliklinik RSUD STS Kabupaten Tebo penulis menggunakan teori inovasi oleh roger dalam (Sumarno, 2008) yaitu : Relative advantage (keuntungan relatif), Compatibility (kesesuaian), Complexity (kerumitan), Trialibility (kemungkinan dilakukan percobaan), Observability (dapat diamati).

\section{Relative advantage (keuntungan relatif)}

Inovasi pelayanan publik E-Pendampingan Halo jaksa Kejaksaan Negeri Tebo tentunya harus memiliki nilai lebih atau tambah dari pelayanan sebelumnya itulah yang disebut dengan Relative Advantage yang dikemukakan oleh rogers tersebut, maka berdasarkan hasil temuan yang peniliti lakukan diatas dapat ditemukan bahwa pelayanan EPendampingan ini memiliki kelebihan serta kemudahan dari pelayanan yang ada sebelumnya.

Hal itu dapat dilihat dari hasil wawancara terhadap kepala Kejaksaan Negeri Tebo bapak Imran yusuf, S.H, M.H yang menjelaskan bahwa tujuan pembentukan EPendampingan ini adalah untuk memudahkan proses mendukung program-program pembangunan yang dilakukan pemerintah Kabupaten Tebo yang pada pelaksanaanya pihak kejaksaan ingin memberikan kemudahan dengan mengadaptasi penggunaan teknologi informasi terlebih juga agar menimalisir kegiatan kontak secara langsung karena melihat situasi dan kondisi pandemi Covid-19 namun, tetap meski dalam keadaan apapun perecepatan pembangunan tidak boleh terhambat.

Penggunaan teknologi informasi dalam hal ini dapat memberikan nilai lebih sehingga tentu dapat memberikan kemudahan-kemudahan yang tentunya sangat efektif dan efisien dalam menjalankan proses pelayanan publik.

Hal tersebut sesuai dengan dampak yang dijelaskan oleh bapak syafei, S.H selaku kepala seksi Perdata dan Tata Usaha Negara bahwa beliau menjelaskan, bahwa pada tahun lalu sebelum ada E-Pendampingan ini bahwa hanya terdapat 10 permohonan pendampingan yang dilakukan tetapi setelah adanya E-Pendampingan ini kejaksaan telah menerima 84 permohonan tentunya hal tersebut menggambar bahwa instansi-instansi pemerintah selaku penerima jasa layanan merasakan ada nilai tambahan kemudahan dari sebelumnya dan meningkatkan minat mereka untuk mengajukan permohonan pendampingan.

\section{Compatibility (kesesuaian).}

Inovasi pelayanan publik E-Pendampingan Halo Jaksa Kejaksaan Negeri Tebo haruslah sesuai dengan aturan-aturan yang berlaku dan sesuai dengan tugas-tugas dan fungsi dari Kejaksaan karena inovasi pelayanan publik hanya merubah atau meningkatkan mutu dari segi proses pelaksanaanya saja tidak boleh merubah aturan dasar hukum tetntang pelayanan tersebut.

Oleh karena itu dilihat dari hasil wawancara bersama bapak Kepala Kejaksaan Negeri Tebo Imran Yusuf, S.H, M.H bahwa E-Pendampingan Halo jaksa ini pada pelaksanaanya berpijak pada UU No 16 Tahun 2004 pasal 30 tentang Kejaksaan Republik Indonesia dan PER-025/A/JA/11/2015 Tentang Petunjuk Pelaksanaan Penegakan Hukum, Bantuan Hukum, Pertimbangan Hukum, Tindakan Hukum Lain, Dan Pelayanan Hukum Di Bidang Perdata Dan Tata Usaha Negara. Yang hinga kini masihh berlaku dan belum ada perubahan sama sekali.

Oleh karena itu dapat di simpulkan bahwa kesesuian inovasi pelayanan publik EPendampingan Halo Jaksa Kejaksaan Negeri Tebo sesuai dengan teori Compatibility (kesesuaian) dalam hal ini kesesuaian dengan tugas dan fungi pelayanan tersebut sendiri dan tidak bertentangan dengan aturan-aturan yang mendasari inovasi pelayanan publik tersebut ada. 


\section{Complexity (kerumitan).}

Inovasi pelayanan publik harus lah memiliki tingkat kerumitan yang lebih mudah dari pada pelayanan yang ada sebelumnya dalam hal ini E-Pendampingan Halo Jaksa Kejaksaan Negeri Tebo tentunya sebagai inovasi pelayanan publik yang telah mengadaptasi teknologi informasi didalamnya tentunya haruslah memiliki tingkat kerumitan yang tidak sulit khususnya bila diakses oleh penggunan layanan E-Pendampingan Halo jaksa.

Berdasarkan hasil wawancara peneliti bersama kepala seksi Perdata dan Tata Usaha Negara Kejaksaan Negeri Tebo Syafei, S.H bahwa tentunya seperti yang sudah disinggung pada prinsip relative advantage bahwa inovasi E-Pedampingan ini memiliki nilai tambah dikarenakan menerapkan pemanfaatan teknologi informasi hal tersbut juga secara otomatis memepengaruhi tingkat kerumitan dalam prosesnya pelaksanaanya dinilai efektif dan efisien itu terlihat dengan meningkatkan tingkat permohonan pendampingan memlalui Ependampingan ini yang sebelumnya hanya 10 ditahun 2020 tetapi di tahun 2021 hingga wawancara dilakukan telah ada 84 pelayanan pendampingan yang dilakukan melalui Ependampingan Halo jaksa Kejaksaan Negeri Tebo.

4. Trialibility (kemungkinan dilakukan percobaan).

Trialibility dapat diartikan sebagai proses uji coba sebelum inovasi pelayanan publik ini diterapkan secara resmi dan juga dimanfaatkan sebagai masa sosialisasi inovasi pelayanan publik tersebut kepada para stekholder terkait inovasi pelayanan publik dalam hal ini yaitu E-Pendampingan Halo jaksa Kejaksaan Negeri Tebo.

Berdasarkan temuan peniliti dari hasil wawancara bersama bapak Syafei, S.H bahwa pada awalnya E-pendampingan ini terbentuk setelah adanya penandatanganan Mou atau nota kesepahaman antara Pemerintah kabupaten tebo dan kejaksaan negeri Tebo dimana nota kesepahaman tersebut sebagai dasar pelaksanaan E-Pendampingan Halo Jaksa dalam melaksanakan permohonan pendampingan oleh pihak satuan kerja perangkat daerah jadi dapat disimpulkan pertama bahwa pada pelaksanaan pendampingan ini dilaksankan jika adanya permohonan yang diajukan jadi kejaksaan akan dapat masuk melakukan pendampingan dan memantau jalanya pendampingan harus diawali dengan adanya permohonan ini untuk mencegah terjadinya praktek-praktek jaksa-jaksa nakal.

Penandatanganan yang dilakukan pada 16 februari dan setelah itu pada maret hingga mei Kejaksaan melakukan proses percobaan dan sosialisasi dengan tujuan dilakukan masa percobaan ini menurut kepala seksi DATUN bapak syafei, S.H agar dapat dilihat apakah adanya hambatan serta error nantinya selama pelaksanaan E-Pendampingan ini dan jika ada dapat dilakukan perbaikan segera sehingga menimalisir terjadinya error pada pelaksaanaan nantinya dan sosialisasi juga dilakukan guna untuk memberitahu dan menjelaskan bagaiamana proses atau alur pelayanan E-pendampingan ini kepada stekholder sehingga nantinya dengan telah adanya sosialisasi maka para stekholder dapat segera menggunakanya tanpa harus ragu dan bingu tentang tata cara dan alur pelayanan E-Pendampingan Halo Jaksa Kejaksaan Negeri Tebo.

\section{Observability (dapat diamati)}

Berikutnya inovasi pelayanan publik haruslah dapat diamati kinerja serta outputnya oleh berbagai pihak agar ketika inovasi pelayanan publik tersebut dapat berjalan dan menghasilkan output yang baik makan akan menjadi hal yang dapat ditiru oleh instansiinstansi lain yang akan memulai melakukan inovasi-inovasi sehingga tercipta pemerintahan yang inovatif dan produktif menghasilkan pelayanan-pelayanan yang memiliki mutu yang baik.

Dan setelah adanya proses masa percobaan penerapan inovasi pelayanan publik EPendampingan tersbut secara resmi dilakukan agar dapat diamati serta mengetahui hasil atau outpout yang didapatkan dari inovasi pelayanan Publik E-Pendampingan Halo Jaksa 
Kejaksaan Negeri Tebo. Salah satu contoh kasus atau permasalahan yang peneliti ambil untuk mengetahui bagaimana inovasi pelayanan Publik E-Pendampingan Halo Jaksa Kejaksaan Negeri Tebo mengatasi permasalahan pembangunan di tebo yaitu permasalahan pembangunan gedung poliklinik RSUD Sultan Thaha Syaifudin Kabupaten Tebo.

Maka dari hasil wawancara peneliti bersama bapak Yulian Yusma, S.T selaku konsultan CV. Belimbing Seriwijaya dalam proyek pembanguna gedung poliklinik RSUD STS Tebo dapat disimpulkan bahwa peembngunan poliklinik RSUD tersmbut mengalami keterhambatan karena adanya tenaga kerja mereka yang dari pulau jawa tengah tidak dapat datang ke Tebo dikarenakan adanya kebijkan PPKM oleh pemerintah sehingga mereka meberitahu perihal permasalahan tersebut kepada pihak Dinas PUPR dan pihak RSUD tetapi baik dinas PUPR dan RSUD tidak dapat meberikan dikarenkan takut menyalahi aturan yang ada.

Oleh karena itu pihak RSUD pengajukan permohonan pendampingan kepada Kejaksaan Negeri Tebo yang proses pengajuanya di lakukan melalui E-Pendampingan yang terdapat pada website Kejaksaan Negeri Tebo. Berdasarkan wawancara bersama bapak Syafei, S.H peneliti menanyakan bagaiamana proses dan apa saja fitur yang terdapat dalam E-Pendampinga tersebut dan dari hasil wawancara dapat disimpulkan bahwa proses pengajuan permohonan sebelumnya di awali dengan pihak RSUD STS Tebo mengontak admin IT kejaksaan melalui nomo Whatsapp resmi dilaman Website Kejaksaan Negeri Tebo menyampaikan perihal bahwa pihak rumah sakit mengalami kendala dan ingin mengajukan pendampingan kepada pihak Kejaksaan Negeri Tebo.

Maka pihak kejaksaan dalam 1x24 jam akan memberikan username dan password akun E-Pendampingan yang telah dibuatkan untuk pihak rumah skait dan juga memasukan admin E-Pendampingan dari pihak rumah sakit kedalam grup Whatsapp Pendampingan selanjutnya admin Rumah sakit mengupload surat permohonan pendampingan yang ditujukan kepada kepala Kejaksaan Negeri Tebo dan selanjutnya pihak kejaksaan setelah menerima surat permohonan akan mengeluarkan surat perintah kepada para jaksa yang diperintahkan untuk nantinya akan melakukan pendampingan terhadap proyek pembangunan gedung Poliklinik RSUD STS Tebo.

Dan selanjuntya didalam fitur E-Pendampingan terdapat juga dialog interaktif yang dapat digunakan untuk berkomunikasi antar para pihak yang terlibat pada proses pendampingan tersebut. Juga pihak Kejaksaan memelalui admin E-Pendampingan meminta juga kepada pihak RSUD untuk memasukan progres pembangunan, seperti foto pembangunan, progres pembangunna, biaya pembangunna, kontraktor terlibat serta lamanya masa pembangunan, yang nanti guna sebagai bentuk keterbukaan informasi sehingga nantinya seluruh proses akan ditampilkan di halaman website E-Pendampingan sehingga masyarakat dapat melihat bagaimana progres-progres pembangunan yang terjadi di kabupaten Tebo dan ikut memantau jika adanya pemasalahan yang terjadi.

Selanjutnya setelah surat perintah dikeluarkan maka pihak kejaksaan akan menandatangi langsung lokasi pembangunan tujuanya guna untuk mengtahui dan mendengarkan langsung dari setiap pihak yang terlibat pada pembangunan baik itu dari pekerja sehingga jika ditemukan permasalahan lainya maka akan dapat di tampung dan sekaligus dicarikan solusinya dan dilokasi pembangunan poliklinik tersbut jika kondisi memungkinkan maka akan langsung dilakukan rapat bersama dan kebetulan pada pembnagunan poliklinik RSUD tersbut memungkinkan dilaksanakanya rapat.

Dalam rapat tersebutlah disampaikan kendala-kendala yang dihadapi oleh pihak RSUD dan pada permasalahan tenaga kerja tersebut Pihak Kejaksaan memebrikan solusi agar pihak PUPR meminta kepada kesekatriat daerah Kabupaten Tebo dibuatkan surat dan dikirimkan kepada pemerintah Provinsi Jawa Tengah yang didalamnya terlampir lengkap 
biodata para pekerja tujuan perjalanan dengan ditanda tangani oleh bupati Tebo meminta agar diberikan akses kepada para pekerja tersebut dengan syarat tetap melakukan protokoler Covid-19 yang lengkap.

Selanjutnya maka menurut keterangan Kepala seksi perdata dan tata usaha Syafei, S.H dalam waktu 5 hari mereka sudat dapat laporan bahwa surat balasan telah diterima dan para pekerja tersbut diberikan akses untuk melakukan perjalanan ke Kabupaten Tebo.

Dan juga dari hasil wawancara bapak Syafei, S.H bahwa dapat didapatkan seperti yang dijelaskan diatas bahwa hanya pihak-pihak tertentu yang diberi akses untuk dapat login kedalam E-Pendampingan Halo Jaksa ini yaitu tentunya pihak Kejaksaan beserta pemohonan, Dinas Pekerjaan Umum dan Perumahaan Rakyat (PUPR)Kabupaten Tebo selaku penanggung jawab pengadaan barang dan jasa pemerintah, lalu Bupati dan wakil bupati, Pimpinan DPRD, Dinas Badan Keungan Daerah (BAKEUDA) Kabupaten Tebo, Inspektorat Kabupaten Tebo, seluruh pihak tersbut diberikan username dan password langsung untuk mengakses E-Pendampingan sehingga proses pengawasan juga dapat dilakukan dengan cepat dan transparan karena sebagai contoh bupati tak perlu lagi menerima laporan dari stafnya atau menanyakan kepada pihak kejaksaan tetapi cukup dengan smartphone dia dapat mengakses dan melihat proses pembangunan tersbut dan mengawasinya secara langsung sehingga tidak ada miss komunikasi yang terjadi.

Dan selanjutnya setelah semua proses pendampingan dilakukan maka pihak Kejaksaan akan memnbuat surat berita acara pendampingan yang digunakan sebagai laporan kepada Kepala Kejaksaan Negeri Tebo dari para jaksa yang bertugas melakukan pendampingan dan juga nantinya sebagai akuntabilitas kinerja para pegawai di Kejaksaan Negeri Tebo dan juga bahan evaluasi terhadap layanan E-Pendampingan agar dapat terus dilakukan pengembangan-pengembangan melalui kritik ataupun saran dari para stekholder.

\section{c. Dampak penerapan Inovasi pelayanan E-Pendampingan dan respon para stekholder tentang adanya inovasi pelayanan publik Halo Jaksa Kejaksaan Negeri Tebo.}

Mengacu pada pemahaman terhadap inovasi, oleh karena itu dapat disimpulkan bahwa suatu pelayanan yang inovatif biasanya disebut praktek terbaik (best Practices). Persatuan Bangsa-bangsa dalam sidangnya, menyepakati bahwa best practices digunakan sebagai indikator dalam meningkatkan kualitas pelayanan publik berdasarkan realitas yang terjadi dilapangan.

Best practice terdiri dari tiga karakteristik yang dikutip dari Report of the Preparatory Committee for the United Nation Conference on Human Setlement yang di presentasikan pada sidang umum PBB Sangkala (2012), yaitu: Dampak (Impact), sebuah inovasi pelayanan publik harus menunjukkan sebuah dampak yang baik serta dapat terlihat langsung manfaatnya dilapangan. Kemitraan (partnership), suatu inovasi pelayanan publik harus didasarkan hubungan kemitraan antara stekholder yang terlibat, setidaknya melibatkan dua pihak. Keberlanjutan (sustainability), sebuah inovasi pelayanan publik harus membawa perubahan dasar dalam wilayah permasalahan dimana inovasi tersebut dibuat.

Dalam penerapan inovasi pelayanan publik E-pendamping tentunya memiliki dampak apa yang menjadi tujuan dari hadirnya inovasi pelayanan itu serta bagaimana respon para stekholder terkait inovasi pelayanan E-Pendampingan Halo Jaksa ini penulis akan menjabarkanya sesuai dengan hasil penelitian yang telah penulis lakukan. Berikut dampak serta respon terkait penerapan inovasi pelayanan E-Pendampingan Halo jaksa Kejaksaan Negeri Tebo :

\section{Dampak.}

Berdasarkan hasil penelitian yang ditemukan oleh penliti melalui wawancara bersama para stekholder serta maka mengacu prinsip best practice yang kemukakan oleh PBB dalam 
(Sangkala, 2012, hal. 8) peneliti menemukan bahwa E-Pendampingan ini memiliki dampak terhadap percepatan proses pembangunan yang berada di Kabupaten Tebo khsusunya.

E-Pendampingan ini memang tujuan utamanya adalah mendukung jalanya proses pembangunan khususnya dalam pengadaan barang dan jasa pemerintah di Kabupaten Tebo itu terbukti dengan proses penyelesaian masalah pembangunan gedung poliklinik RSUD STS Kabupaten Tebo yang dapat diselesaikan melalui E-pendampingan ini. Sesuai dengan hasil wawancara bersama Kepala Kejaksaan Negeri Tebo terlihat bahwa E-Pendampingan ini menerapkan teknologi informasi didalamnya sehingga memberikan keefektifan dan keefisiensian dalam pelaksanaanya dan hal tersebut juga diakui oleh para stekholder yang terlibat sebagai pengguna layanan E-pendampingan Halo Jaksa Kejaksaan Negeri Tebo. Serta juga menimalisir kegiatan pelayanan yang mengaruskan tatap muka langsung melihat kita dalam kondisi pandemi-covid 19 dan kegiatan survey dilapangan pun dilakukan dengan Protokol Kesehatan yang ketat sehingga dapat menimalisir juga lajur penyebaran covid-19 saat ini.

\section{Kemitraan}

Berdasarkan hasil temuan dan wawancara yang dilakukan tentunya dapat terlihat bahwa E-Pendampingan menjalin kemitraan itu terlihat dengan penjelasan yang disampaikan oleh Kepala Seksi Perdata dan Tata Usaha Negara Kejaksaan Negeri Tebo Syafei, S.H bahwa E-pendampingan ini melibatkan beberapa stekholder tetntunya yang terlibat dalam proses-proses pengadaan barang jasa di pemerintahan Kabupaten Tebo seperti contohnya Pihak Dinas PUPR, pihak RSUD STS Tebo, pihak konsultan proyek pembangunan poliklinik di RSUD STS Tebo, dan para pengawas yaitu Bupat dan wakil, dan Ketua dan wakil DPRD selaku pimpinan daerah, Inspektorat dan Badan Keuangan Daerah (BAKEUDA) kabupaten Tebo selaku auditor serta tentunya masyrakat dikabupaten Tebo Itu sendiri. Sehingga terjalin kemitraan dan sinegritas antara para stekholder yang terlibat dalam pelayanan E-pendampingan Halo Jaksa Kejaksaan Negeri Tebo.

\section{Keberlanjutan}

Dari hasil wawancara yang dilakukan oleh peneliti maka penliti dapat melihat adanya dukungan terhadap keberlanjutan inovasi Pelayanan Publik ini kedepanya melalui para aktoraktor yang terlibat yang khususnya peneliti ambil dari permasalahan pembangunan gedung poliklinik RSUD STS kabupaten Tebo, yang mana dapat dilihat dari pihak mitra proyek pembangunan yaitu Konsultan proyek, pihak dinas PUPR serta pihak RSUD STS dan masyarakat kabupaten Tebo itu sendiri memiliki sikap pro aktif dan mendukung sekali terhadap keberlanjutan inovasi pelayanan E-Pendampingan Halo Jaksa ini serta komitmen dari pimpinan Kejaksaan Negeri Tebo serta seluruh pegawai didalamnya memiliki sikap positif dan pro aktif juga dalam mewujudkan keberlangsungan jalanya inovasi pelayanan EPendampingan Halo Jaksa Kejaksaan Negeri Tebo ini kedepan.

\section{KESIMPULAN}

Berdasarkan hasil penelitian dan pembahasan yang penulis lakukan, maka dapat ditarik kesimpulan sebagai berikut :

a. E-Pendampingan merupakan inovasi pelayanan dari Kejaksaan Negeri Tebo dalam bidang Perdata dan Tata Usaha Negara dalam mendukung Proses jalanya Proses pembangunan di kabupaten Tebo khususnya dalam proses pengadaan barang dan jasa oleh Pemerintah Kabupaten Tebo. Layanan ini berupa pemberian Pendampingan Hukum (legal Assistance). Dalam pengatasan masalah pembangunan gedung poliklinik RSUD STS Tebo melalui Ependampingan, diawali dengan pihak RSUD pengajukan surat permohonan yang di upload ke dalam E-Pendampingan yang terdapat di Website Kejari Tebo, selanjutnya Kejaksaan mengeluarkan surat perintah pendampingan dan diupload juga kedalam E-pendampingan serta 
selanjutnya meminta pihak RSUD untuk mengunggah serta progres pembangunan yang tujuanya untuk memberikan informasi seputar progres pembangunan kepada semua stekholder, lalu selanjutnya kejaksaan pendatangi lokasi pembangunan dan melakukan rapat bersama pihak PUPR, RSUD serta kontraktor mencarikan solusi terhdap permasalahan pembangunan poliklinik dan selanjutnya setelah ditemukan solusi maka pihak kejaksaan membuatkan berita acara pendampingan yang ditujukanj sebagai laporan kepada pimpinan Kejaksaan Negeri Tebo.

b. Dilihat dari pembahasan dapat dispimpulkan bahwa inovasi pelayanan E-pendampingan ini memiliki dampak yang positif yang dapat dilihat terjalinya kemitraan antar stekholder melalui E-Pendampingan ini dalam usaha mendukung proses Pembangunan Di kabupaten Tebo. Lalu adanya respon positif terhadap keberlanjutan inovasi Pelayanan E-Pendampingan ini dilihat dari adanya komitmen sendiri dari pihak kejaksaan dalam usaha mempertahankan serta meningkatkan inovasi E-Pendampingan ini kedepanya serta respon positif berupa dukungan dari pada aktor-aktor yang terlibat didalam E-Pendampingan Halo Jaksa Kejaksaan Negeri Tebo.

\section{DAFTAR PUSTAKA}

\section{Buku}

Bratakusumah, D. supriadi. (2004). Perencanaan Pembangunan Daerah. Jakarta: Gramedia Pustaka Utama.

Bungin, B. (2015). Penelitian Kulaitatif edisi Kedua. Jakarta: Kencana Prenada Media.

Burhan, B. (2010). Metodelogi Penelitian kulaitatif. Jakarta: PT. Raja GrafindoPersada.

Denhardt, J.V. \& Denhardt, R. . (2015). The New Public Service: Serving, Not Steering: Third Edition. New York: Routledge.

Dwiyanto, A. (2006). Mewujudkan Good Governance Melalui Pelayanan Publik. Yogyakarta: UGM Press.

Huberman, M. B. M. dan M. (1992). Analisis Data Kualitatif (T. R. Rohid (ed.)). Jakarta: UI-Press. Muri, Y. (2015). Metode Penelitian. Jakarta: Prenada Media.

Sangkala. (2012). Dimensi-Dimensi Manajemen Publik. Yogyakarta: Ombak.

Sondang P. Siagian. (2000). Administrasi Pembangunan. Jakarta: Bumi Aksara.

Sugiyono. (2016). Metode Penelitian, Kuantitaif, Kualitatif dan R\&D. PT Bandung; Alfabeta.

Sumarno, Y. (2008). Inovasi Di Sektor Publik. Bandung: STIA LAN Press.

Wibawa, S. (2009). Administrasi Negara Dan Isu-ius Kontemporer. Yogyakarta: Graha Ilmu.

Jurnal

Darmi, T, S. (2016). Good Governance Implementing into Social Assistance Management Known as (Bansos). ICPM 2016 International Conference on Public Management. Jurnal Manajemen Publik Dan Kebijakan Publik, 3, 308-309.

Nugroho, H. C. (2014). Koordinasi Pelaksanaan Program Pengembangan Kawasan Agropolitan Di Kabupaten Nganjuk. Jurnal J-PAL, 5(1), 12-22.

Novi Prisma Yunita, R. D. A. (2018). Kondisi Terkini Pelaksanaan E-Goverment Di Indonesia: Analisis Website. Seminar Nasional Teknologi Informasi Dan Komunikasi, 2089-9815, 329-335.

Tahir \& Harakan. (2017). Inovasi Program Kesehatan 24 Jam dalam Mewujudkan Good Health Care Governance Di Kabupaten Bantaeng. Jurnal Muqoddimah, 2(1), 13-22.

Iqbal, M. (2007). Analisis Pemangku Kepentingan Dan Implementasinya dalam Pembangunan Pertanian. Jurnal Litbang Pertanian, 26(3), 89-90.

\section{Dasar aturan}

Undang-Undang Nomor. 16 Tahun 2004 Tentang Kejaksaan Republik Indonesia

Undang-Undang No 25 Tahun 2009 Pelayanan Publik. 
Peraturan Jaksa Agung Republik Indonesia Nomor : PER-025/A/JA/11/2015 Tentang Petunjuk Pelaksanaan Penegakan Hukum, Bantuan Hukum, Pertimbangan Hukum, Tindakan Hukum Lain, Dan Pelayanan Hukum Di Bidang Perdata Dan Tata Usaha Negara.

Nota Kesepakatan atau (MOU) Nomor 188/04/Hk/2021 dan B-406/L.5.17/Gs/02/2021 antara Kejaksaan Negeri Tebo dan Pemerintah Kabupaten Tebo tentang penanganan permasalahan hukum dibidang Perdata Dan Tata Usaha Negara.

Keputusan Menteri Pemberdayaan Aparatur Negara No. 63 Tahun 2003 Tentang Pedoman Umum Penyelenggaraan Pelayanan Publik.

Peraturan Menteri PANRB No. 30 Tahun 2014 Tentang Pedoman Inovasi Pelayanan Publik. 